\title{
Sinclair Wetlands: A case study of practice-led research in community projects
}

This paper documents two community art projects with Glen Reilly, kaitiaki for Sinclair Wetlands. It has two parts: research undertaken for the Sinclair Wetlands projects and a reflection on practiceled research as a methodology based on Sinclair Wetlands as the research topic. The Create Art and Plant Trees project was an area of investigation during my postgraduate study in 2019 to frame my research around human emotions within the natural environment. A second project for the "Art+Water: Mountains to the Sea" exhibition was a community-engaged art project, designed to foster collaborations and positive emotions between artists and the community. The framework consisted of a research topic supported with interdisciplinary theories, practice-led research methodology and studio practice. This paper demonstrates how practice-led projects influenced my postgraduate research and reflects on this learning experience from both academic and community perspectives.

Using art to raise awareness for environmental issues through community projects is not a new concept. According to a study by Rachel Clarke et al, socially engaged art in a community increases the community's sustained engagement. ${ }^{1}$ They suggested that art expresses alternative imaginaries, with a responsive method to enrich participants' experience in the community. Further, art embraces the ambiguity of academic and community participation. ${ }^{2}$ Many studies have shown community projects have tacitly contributed to practice-led research as an experimental testing-ground for the creative process. Typically, any practical activities able to demonstrate a new understanding in the academic world, and its impact on our society, can be defined as practice-led research. ${ }^{3}$ This matches Scrivener's argument that the goal of visual art research generates new comprehension from the original investigation, where both the activity and purpose of investigations may be revised until the goals of the project have been satisfied. ${ }^{4}$

As a kinaesthetic learner, I learn best through creating mini discovery projects. I am influenced by Maarit Anna Mäkelä's argument that we can learn or "know" through making, with art-making being a process of contextualisation through interactive experiences, interpretation of works, multivalent ideas, problem solving, and conversations along the way, revealing surprising insights. ${ }^{5}$ 
As the project name suggests, Create Art and Plant Trees, we created art and planted trees at the wetlands. To plan and conduct the tree planting activities involved a collaboration from Otago Polytechnic Sustainable Practice (Jen Rodgers), Sinclair Wetlands (Glen Reilly), and supportive volunteers - Karen Spreckley, Young Wei Lim, Cissy Sun and Kathryn van Beek. We arranged transportation, food, and activities at the Sinclair Wetlands for an all - day trip for students who study English language at the Otago Polytechnic. This introduced the existence of the Sinclair Wetlands to many new people (Figure 1). As a key coordinator for this project, the challenges were how to organise all the resources and meet the interests of all community groups under the objective of creating art and planting trees.

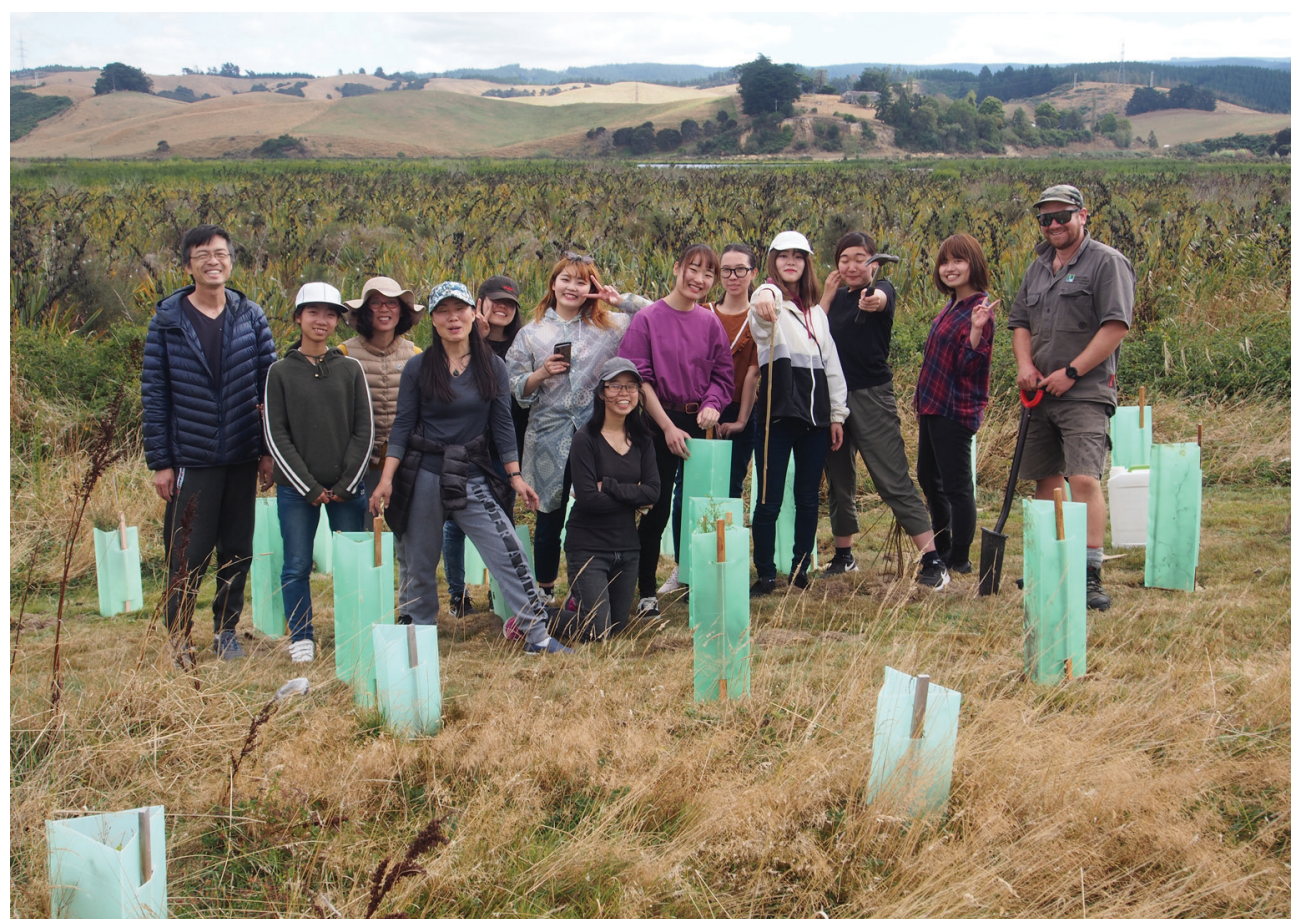

Figure 1. Create Art and Plant Trees project at the Sinclair Wetlands, March 2019.

The "Art+Water" project pushed the Create Art and Plant Trees community project to another level of research, which focused on the theme of water. Both projects encouraged the quality of "soliphilia" for a positive relationship with nature. Glenn Albrecht, former Professor of Sustainability at Murdoch University, coined the term soliphilia to express the sense of nurturing people's feelings of personal responsibility for nature and sustainable living. ${ }^{6}$ We often neglect our own behavioural psychology while trying to make effective policies and better technology solutions in environmental issues. Neville Ellis and Ashlee Cunsolo suggest that people increasingly feel unaligned emotions which occur at individual and societal levels. ${ }^{7}$ They suggest another relevant term, "ecological grief", is exemplified as climate-related ecological loss that people identify in their experience for the loss of ecosystem, species or place. ${ }^{8}$ They coined the term to describe mental health issues affecting both the Inuit Land Claim Settlement Area of Nunatsiavut, Canada, and farmers in the 
Western Australia wheat belt who struggle to cope both emotionally and psychologically with an uncertain future. ${ }^{9}$ Glenn Albrecht described ecological grief in psychological terms as "solastalgia", or the disturbance in humans' minds that arises as a response to a change in their biophysical environment. In simple terms, solastalgia can be understood as "the loss of sense of place". ${ }^{10}$ Albrecht thinks that psychologically acknowledging our silent distress regarding the changes in our environment is crucial for social impacts on environmental sustainability.

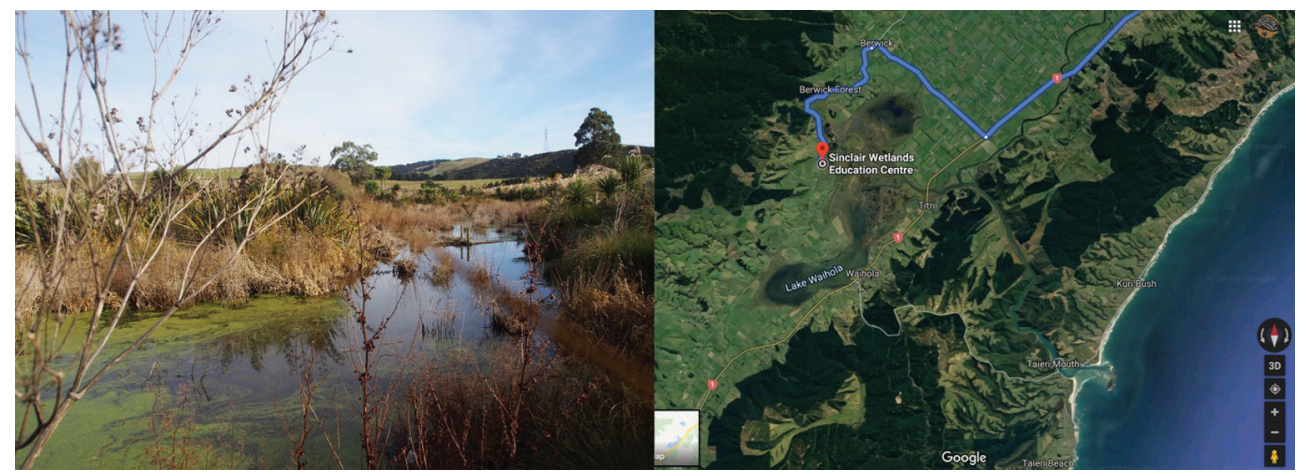

Figure 2. The Sinclair Wetlands and location on Google Maps.

for community. The Sinclair Wetlands were previously owned by Horrie Sinclair, who purchased the property in 1960 when it was farmland and disabled the drainage pumps to revert the area to the wetland. In 1984, Mr Sinclair gifted the wetlands to Ducks Unlimited New Zealand Inc., and in 1998, the Crown returned this property to Te Rūnanga o Kāi Tahu ownership, as part of the Kāi Tahu Claims Settlement Act. Historically, the land belonged to a local chief Tukiauau and his Ngāti Mamoe iwi. ${ }^{11}$ Today the wetland is primarily under the supervision of The Sinclair Wetlands Trust, which aims to protect and restore the wetland. It also aims to promote spiritual, physical, ecological, and cultural engagement, encourages scientific research, and educational teaching outside the classroom on around 315.3 hectares of land. Volunteers from the Conservation Corps, Taskforce Green, Forest and Bird, and other conservation groups have helped plant, release, and mulch the first two years' plantings. An estimated 64,000 native trees and shrubs will be required over the next ten years to replant the Ram and Lonely Islands and higher ground. The aim is to produce 3,000 native plants a year on-site for these restoration projects. ${ }^{12}$

Wetlands function as a water resource to drain and store water through a hydrological process of inflow and outflow from streams, rivers, land, and mountains. ${ }^{13}$ My creative contextualisation and sense of place was embodied in a painted installation - Walk within the water (Figure 4). It is comprised of six vertical paintings on cotton sheeting, hung on flax stalks from the ceiling, allowing the audience to walk through the painting installation. It was painted with thin acrylic, fluidly, using print and mark-making techniques on the cotton sheeting. The intention was to encourage interaction from the audience to experience a visual interpretation of water in the wetlands. The work was hung in front of a glass door under low light, with backlight passing through the sheeting and a view to trees outside. This allowed the cotton sheet to take advantage of reflective light from within the gallery and a view to the outside of the Museum reserve. The movement of walking amongst the panels felt like stepping through the water amidst the gestures of a painted river. 


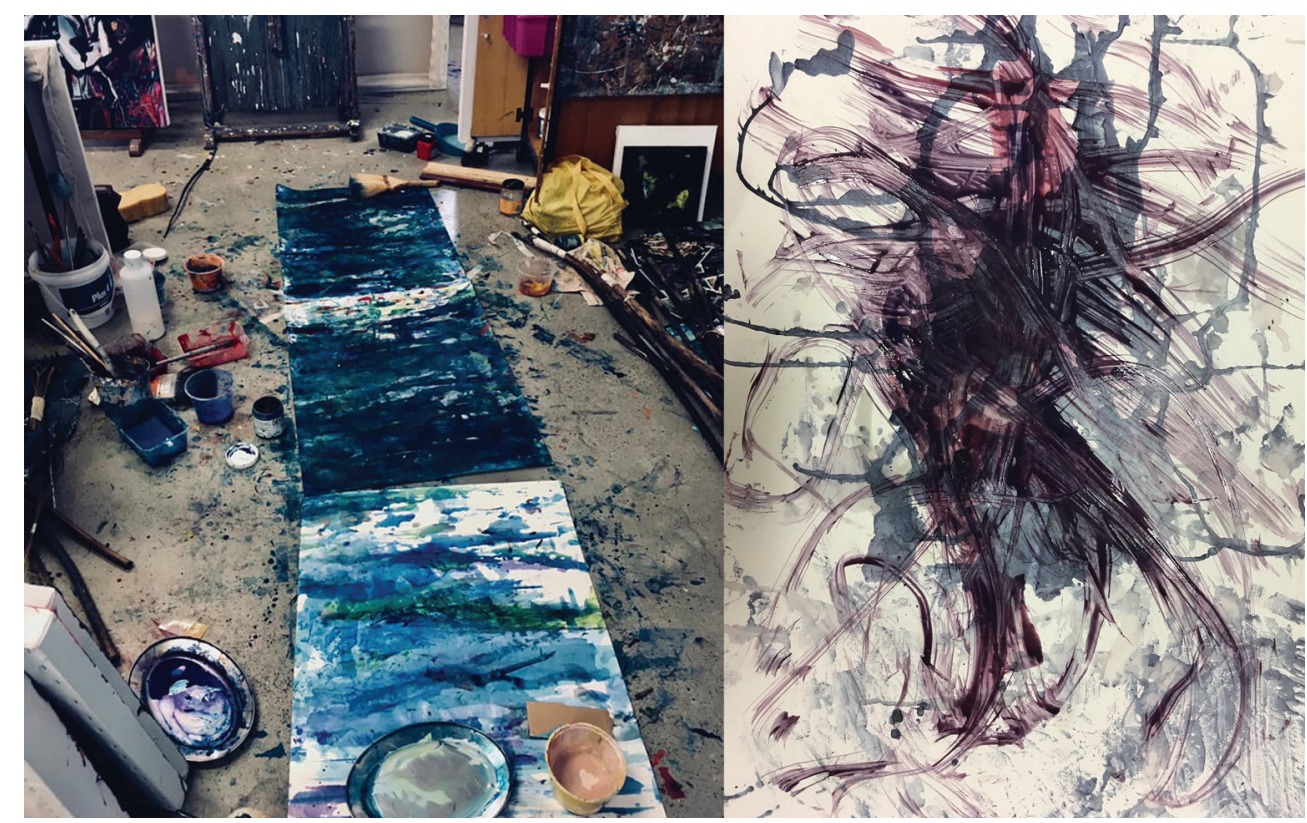

Figure 3. Works in progress - making these works about the Sinclair Wetlands shifted my focus from tree branches, my usual theme in the Anthropocene, to capturing water.
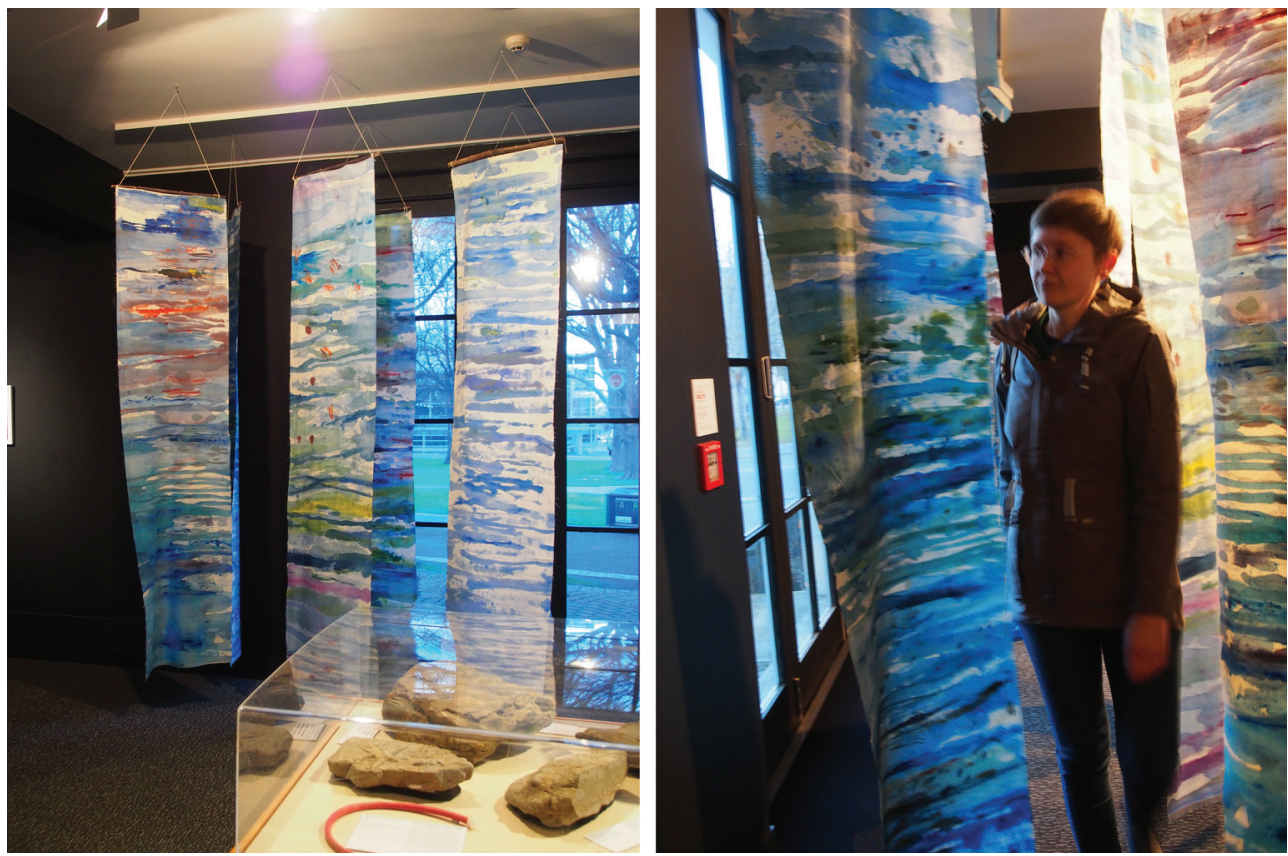

Figure 4. Siau-Jiun Lim, Walk within the water, 2019, painted calico, installation in the Art+Water exhibition, HD Skinner Annex Otago Museum. 
Soliphilia and solastalgia have lived in human emotions for many centuries by many names. The naming of solastalgia, in particular, helps us to understand our nostalgic feelings for place. The environments that we are familiar with, that contribute to our recreational spaces, ecosystems and food chains have been altered in this century. Sinclair Wetlands is a place that holds these qualities, and can be the place where we start to cultivate soliphilia.

Siau-Jiun Lim expresses art through exploration of science, social anthropology, psychology and design that build relationships in an environment. Influenced in her practice by UX/UI and design, she often applies social engagement and experimentation to investigate human behavioural interaction with objects.

1. Rachel Clarke, Jo Briggs, Ann Light, and Peter Wright. Situated Encounters with Socially Engaged Art in Community-Based Design. (Art/ Performance) June 4-8, 2016.https://dl.acm.org/ doi/pdf/10.1145/2901790.2901882

2. Ibid.

3. Judith Mottram, "Asking Questions of Art: Higher Education, Research and Creative Practice," Practice-led Research, Research-led Practice in the Creative Arts (2009): 229-251.

4. Stephen Scrivener and Peter Chapman, "The practical implications of applying a theory of practice based research: A case study," https://www.herts.ac.uk/__data/assets/ pdf_file/0019/12367/WPIAAD_vol3_scrivener_ chapman.pdf

5. Maarit Anna Mäkelä, "Knowing Through Making: The Role of the Artefact in Practice-led Research," Knowledge Theory and Policy, 20, 157-163. doi10.1007/s12130-007-9028-2

6. Glenn Albrecht, "The Psychoterratic in the Symbiocene" in Earth Emotions, New Words for a New World (Ithaca: Cornell University Press, 2019), 121-124.
7. Neville Ellis and Ashlee Cunsolo, “Hope and mourning in the Anthropocene: Understanding ecological grief," The Conversation (April 5, 2018), https://theconversation.com/hope-and-mourningin-the-anthropocene-understanding-ecologicalgrief-88630

8. Ibid.

9. Ibid.

10. Glenn Albrecht, “TEDx SYDNEY Glenn Albrecht Environment Change, Distress \& Human Emotion Solastalgia," TEDxTalks, https://www.youtube. com/watch?v=-GUGW8rOpLY

11. Otago Daily Times, "Living Legacy" (May 8, 2017) https://www.odt.co.nz/lifestyle/magazine/livinglegacy

12. Sinclair Wetlands. "The wetlands," https://www. tenohoaka.org.nz/the-wetlands/

13. Greater Wellington Regional Council, “Understanding the 'wet' in wetlands A guide to the management of freshwater wetland hydrology," http://www.gw.govt.nz/assets/councilpublications/wetland_hydrology.pdf

14. Andrew McNamara, "Six rules for practice-led research," Journal of Writing and Writing Programs S14 (2012): 1-15, https://eprints.qut.edu. au/54808/15/McNamara.PLR.pdf 